\section{ABSTRACT OF DISCUSSION}

DR. F. R. Tsw1s, Jubuque, lowa: In considering the fathologic conditions of the nasal and accessory nasal tissues, it must be remembered that a majority are due directly to infections, and of the remainder a large number are due indirectly to precxistent or coexistent infections. The subject of Dr. Walter's paper is, therefore, of practical interest to all who have to deal with these conditions. Inasmuch as there are involved two widely diflering antagonists, the invacling organism and the invaded tissues, analysis must proceed from two widely differing standpoints, that of the bacteriologist and that of the clinician. Observations which are to form the basis for deductions as to the bacteriologic or the clinieal side of the mitter must be made by experts and the bacteriologic expert should not dwell in the boly of the elinician, and vice retsa.

Among the deductions, certainties may or may not present; mocertainties are bound to. Undue emphasis should be spared the former and accorded the latter.

The funlamental reasons underlying the immunity of certain tissues and the susceptibility of other tissues apparently similar, in the same individual, to the same infection, may not be fortheoming. For instanre, a gonococeus, bathing in mueous emulsion the newly born head, harms not the orn] mucosa. or the nasal mucosn, but does attack the ocular mucosic. Fet that same oral mucosa, scatheless from its meomiter with the gonococens, falls ensy prey to the leptothrix or saceloromycetic infections, whieh in turn do not attuck the conjunctiva; the same nasal mucosa oflers but wak resistance to pneumobacillus or streptococeus. Why? The Morax-Axenfeld bacillus conjunetivitis proceeds minterjupted in the presence of bichlorid of mereury or silver salts but succumbs to \%ine sulphite, wherens the more virulent gonococens enjunctivitis subsides under the influence of silver salts but is not aflected by rine sulphate. Why? Questions like these must remain unanswered until careful investigations, patiently pursued and zealonsly guarded against error, shall lave built up little by little.a knowledge of the subject founded on truths proved by oft-repeated observations. I wish to express the appreciation which $I \mathrm{am}$ sure we all feel in regarl to Dr. IValter's patience and energy.

I want to voice a suggestion concerning nomenclature which may be of some practical value. In specalking of the pharyngitis, tonsillitis, or rllinitis due to the Bacillus diphtherite we are wont to use the terms nasal diphtherin, diphtheritic consillitio or diplutheritic plaryugitis. lin speaking of other forms of phorygitis, tonsillitis or otler inflammation specified aceording to site, of known etiology, sliould we adopt the custom of using etiologic terms, it scems to me we should lave made a step in ndvalue, albeit a small one.

DR. W. S. Anomson, Detroit: Why do infections of the mucous membrane of the lower respiratory tract oecur? Wo all have patients who very seldom have an acute cold, and we latwe other patients who repeatedly have acute colds. We know tlut the lower animals are comparatively fiee from these infections. Why? What is there in the normal mucous membraue of some persons that resists infection while that of others does not? As I understand it, the nolmal respipatory tract is sterile, or nearly so. In the nose there are always a few micro-organisms but they do not thrive on a licalthy mucous membrane. Going downward we find fewer and fower germs until the tract below the vocal cords is alway sterile in a healthy subject. But, in the presence of an acute cold there will be an abundant growth of organisms along the whole respiratory tract. Why? I lave done some work in animals and it is easy to show that the lower respiratory trnet is sterile but in many conditions it becomes infected. The nose of a dog will be followed by a copious growth in the lower respiratory tract. Now we are coming to believe that many of the infectious disenses gain entrance through the mucous membrane of the respiratory tract, meningitis, diphtheria and so forth. In many of these there are local lesions of the mucous membrane, and yet if you attempt to reproduce these lesions in the lower animals rou will fail. I have tried over and over again with the lilebs. Woffer bacillus and have always failed, and yet if we inject the orgnuisms into the blood of the nnimals, they will die immediately or in twenty-four to fortyeight hours. The same thing occurs with the organism of pheumonia. If you rub it on the mucous membrane of the respiratory tract you will get no results at all. Why is the membrane in some ases so resistant? If we could learn what the local condition of the respiratory tract is that favors infection it would explain a great many conditions.

Dr. Wit. WaITEn, Chicago: Infection of the normal mucosa was not investigated but $\mathrm{I}$ jeported the investigntions of others who compare the normal with the abnormal. As to resistance to infection, of course there is the local resistance and the general immunity to be considered. There is also at variation in virulence of infectors and doubtless a specific lowi resistance. These are the problems which the laboratories of the world are trying to solve and which may not be answered offhand. In obstructed noses we have from mechanical eauses practically a stasis and hence lowered local resistanee. The opsonic index may be as high as 2 or 2.50 and still you get infection because of this stasis and the consequent poor local resistance. If the nose is shut oft from its function by such abnormalitios or by being held closed infeetion naturally oecurs lower in the tract. Protection against such infection is one of the reasons for the existence of the nose.

\section{A CLINICAL STUUD OF A CASE OF PSEUDO- LEUKEMIC ANEMIA OF INFANCY} (VON JAKSCII) *

THEODORE J. EJTERTCH, M.D. PitTsisura, I' $\Lambda$.

In 1889, von Jaksch proposed the term "anemia psendoleukemica infuntum" to designate a pathologic picture characterized by oligocythemia, oligochromemia, considerable permanent lenkocytosis, enlarged spleen, slightly enlarged liver, and, sometimes also, enlarged lymph-nodes. Its jelentity as a distinct disease has been seriously questioned by some authorities on diseases of the blood. Notwithstanding, however, we find in a certain number of infants suffering from a severe form of rachitis or hereditary syphilis, a symptom-complex which is entirely apart from the pre-existing disease.

$\Lambda$ number of German authors, Japha, Fischl and Geissler and also some Italians include the grave infantile anemias in the secondary ancmias with a toxic basis, practically as a middle condition between anemia and leukemia. Japha does not regard the spleen as the primary focus, and is of the opinion that it has nothing to do with the regeneration of the blood; this is based on the lact that the enlargement frequently becomes ieduced before the blood-picture has become normal, while the extent of the enlargement does not correspond to the gravity of the anemia. Japha also belicves that deficient new formation of blood constitutes the nature of the affection. At the same time, there may be an exnggerated destruction; but there are only a few cases in which the anemic (granular) degeneration of the red corpuscles is found as a positive evidence of blood poison.

A very notable work on this subject by Banti appeared in 1883 . He believed that anemia splenica was a primary disease of the spleen, but he also considered it a splenic form of leukemia. In the case studied and described by him, there were marked fibrous changes in

* liend in the Section on Disenses of Childien of the American Medlcal $\Lambda$ ssoclation, at the Sixty-fir'st $\Lambda$ unual Sesslon, held at $\mathbf{S t}$ Lolls, June, 1010. 
the trabecula and the follicles of the spleen; and a great diminution of the cells. There were many phagocytic cells containing red corpuscles; the bone-marrow was red and showed a lymphoid condition, but the lymphnodes were enlarged. The spleen weighed 2 pounds, 7 ounces; the liver weighed 2 pounds, 121/2 ounces. The blood showed a diminution of leukocytes and the red corpuseles were between $2,000,000$ and $3,000,000$ per cubic millimeter. Koplik reports nine cases in which the blood-picture was as follows:

The hemoglobin ranged from 28 to $85 \mathrm{per}$ cent.; the count of red blood-eclls or erythrocytes fell as low as $1,400,000$ and in others was as high as $4,448,000$; and the leukocytes ranged from 5,200 to 40,000 and 80,000 to the cubic millimeter. In all cases there were mucleated red blood-cells; normolblasts and megaloblusts from 7 to 15 per cent. In some eases the white cells varied from 10,000 to 80,000 to the cubic millimeter in a given ease, with erythrocyte count of $2,699,999$ to $3,799,999$.

He regards yon Jaksch's anemia as a severe secondary anemia with or without marked leukocytosis.

Monti and Berggruen report 20 cases. In six of these the red eells were below 1,600,000. Four cases proved fatal; one recovered in which the proportion of leukocytes to the red cells had been 1 to 12 .

History.-The case which I observed was that of a male child aged 13 months, admitted to the children's ward of the Allegheny General Hospital, Pittslurg, Aug. 4, 1909. The father and mother are loth of German parentage and are apparently in good health. There is no history of tuberculosis or syphilis. The patient was one of twins; the other died at the age of 2 months from dinrrheal affection. The patient had always been a weak and delicate baby. He was breast-fed for a few weeks only, and then fed on various foods, principally condensed milk. He had always been pale and eries a great deal. He had never been known to smile.

Hxamination.-'Jhe child was very poorly nourished and anemic. His expression was often anxious; but, as a rule he seemed apathetic. The skin was dry and flably. Numerous purpurje spots were seen in. various parts of the body, partic. warly in the legs and over the right iliac region. J'here was considerable enlargement of the lymphatic glunds in the cervical, axillary, and inguinal regions. The abdomen was distended. 'The anterior fontanel was open and about the size of a twenty-live cent piece. The child had but six tecth. The epiphyses of the forearms were enlarged. Rachitic rosary, well inarked. Examination of the chest revealed a subucute bronchitis. The lieart-sounds were clear and distinct. The liver was found to be enlarged, extending several fingerbreadths below the costal eartilages. The spleen was enormously onlargel, the tumor extending far below and to within half an inch of the umbilicus. The noteh of the spleen could be felt plainly. There seems to be some pain on palpation. dixamination of urine was negative. The examination of the blood showed 27,500 whites, 2,500,000 reds and $45 \mathrm{per}$ cent. of hemoglobin.

Course of Disease.-The foregoing is a description of the condition of the patient on admission to the hospital. He remaned in the institution until the time of his death, Aug. 26, J900, twenty-two days after admission. The progress of the disease was rather rapid and influenced to a considerable degree by intereurrent uffections and eonditions.

Temperature: On admission, his temperature was slightly above normul, but during the course of the disense varied from $101^{\circ}$ to $104^{\circ} \mathrm{F}$. purtly due to a bronchopmenmonia and " purulent inflammation of the middle ear, which occurred on the tenth and twelfth days, respectively, after admission.

I'ulse: The pulse was japid, never below 120, but, until shortly before his death, of fair quality.

Weight: From 15 pounds and 9 ounces, the weight fell lapidly to 13 pounds during the first week. Later there was a gain of about half a pound, which was followed by a rapicl decline, reaching 11 pounds on the day of the patient's death.
Skin: In addition to the purpura, which remained and increased thronghout the course of the discase, marked icterus was present shortly before death.

lungs: While, on admission, only a few coarse rales could be heard over his chest, evidenees of a bronehopmenmonia were present on the tenth day and continued up until the time of his death.

Digrestive System: Vomiting and diarrhen oceurred frequently. It was extremely diffieult to find any food which would agree with the patient. Whey and barley-water were alsout the only things which he retained.

Urine: At first the urine was normal, but later after the administration of arsacetin ${ }^{1}$ it contained a large amount of albumin, also a few hyaline and granular casts.

J3lood: As stated above, at the time of admission, the patient had 27,500 whites, these gradually became redueed to 16,000 ; the reds were $2,500,000$ and were reduced to $2,287,000$. 'The hemoglobin remainea about the same, 45 per cent.

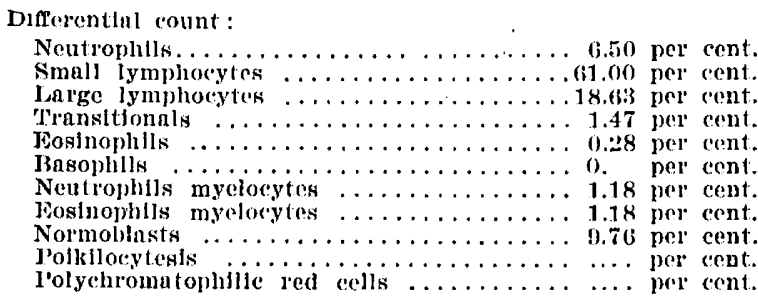

'herapy-Che treatment at first was directed entirely to the digestive organs, calomel and bismuth being employed. later the patient was given arsacetin hypodermatically in doses of $0.05(\mathrm{gr}$. $3 / 4)$ but, on account of the oceurrence of albuninuria had to be discontinued. In addition, iron and stimulants were given.

Summary of Clinical symptoms.-Rachitis, enormous enlargement of the spleen, moderate enlargement of the liver and lymphatic glands, purpura, icterus, bronchopneumonia, otitis media, gastro-intestinnl indigestion, albuminuria.

Autopsy.-This was made by 1)r. 1. P'roescher, Pathologist, Allegheny General llospital.

Spleen, Macroscopic Examination: The spleen measured $10 \mathrm{~cm}$. (4 in.) in length, $8 \mathrm{~cm}$. (3.2 in.) in brendth, and $5 \mathrm{~cm}$. (2 in.) in thickness. It weighed $163 \mathrm{gm}$. (5 o\%. 15 grains) and was therefore about seven times the natural size of the spleen of an infant at that age. Jts consistency was firm and it was deeply notehed at the lower end. The surface was mostly of a light red color, but in some parts, a dark blue discoloration was seen. On section it was found to be of tough consistency. The follienlar markings were obliterated. Numerous irregular but not sharply-defined areas were to be seen. These were about the size of pin-heads, of a grayish white color.

Spleen, Microscopic Examination: The capsule, as well as the trabecula, was thickened. The commertive tissue was deficient in muclei and hyaline in appearnuce. The follicles were completely obliterated. Most remarkable was the great interstitial fibrous induration, which had caused almost complete obliteration of large areas of the pulp. This induration was seen to be partly in the shape of large, irregularly scattered arens of grenter or less thickness, with remmants of pulp tissue, still enclosed; or, in the form of diffusely scattered, isolated fibers, truversing the entire pulp and passing between the pulp cells. These were exceptionally well defined by the Van Giesen staining. Both the smaller and larger vessels also showed considerable fibrous induration, especially the tunica adventitia, which was enormously thickened. In some places there was also a proliferation of the intima, which led to complete ocelusion of the lumen. The enormously thickened adventitia presented a marked tendency to liyaline degeneration. The fibers of the connective tissues were conglomerated into hyaline masses

1. Alsacelin is sodium acetyl arsanllate, a compound derlved from sodfum urannllate. It is claimed to be jess toxic thinn sodium

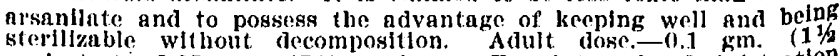

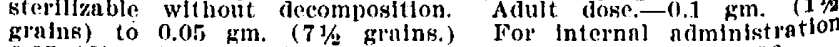
$0.05(\% / 4 \mathrm{gr})$.3 to 4 times dally. See N. N. R., 1910, page 36 
containing no nuclei. 'The lumina of the majority of the blood-vessels were empty, but, where they were filled with blood, erythrocytes pale and indistinct were found, heside which were seen many mononuclear and a few polynuelear cellis.

In adlition, there were seen cavities, either senttered or in groups, or even long and winding, and lined by a single layer of spindle-shlaped endothelial cells. They were enclosed by a dense ring of round cells, some of which were surrounded by a thick lyyaline non-nuclear tissue. That we were not denling with blood-vessels was established by the fact of the uniformity of structure of the surrounding tissue, which allowed of no clistimetion of the different layers of the blood-vessels. Wo were in all probability dealing with a cystic dilatation of the lymplt spacess. The pulp consisted of mumerous blood-cells and round-cell elements of varying si\%s, avernging from 3 to (i microns in diameter. These mostly showed a romd or slightly lobulated nucleus, with seanty protoplasm. Some of the muclei were ricls in chromatin, others showed only a framework of chromatin; muny of the large monomuelear aels showed eosinophil granulations. In addition, a few spindle-shaped cells resembling endothelium cells vere found. Jarge giantlike cells with plagocytic enclosure of red blood cells were scarcely scent.

Jiver, Ancroscopic Examination: The liver was 9 ('m. (31/2 in.) in length, $16 \mathrm{~cm} .(61 / 2 \mathrm{in.})$ in breadth, $4 \mathrm{~cm}$. (11/2 in.) in thickness and weighed $345 \mathrm{gm}$. (11 o\%. $7 / 2$ drams). It was of firm consistency, its ellges were sharp and the color a yellowish red in some places, while in others it was more of a yellowish color. On section it was of a bright yellow or red color. The acinous delineations were quile plainly visible. At the periphery the acini were of a sulphur yellowish color; but. in the center more of a yellowish red and cloudy. Throughout the entire parenchyma there were numerous punctiform liemorrhages. The vessels were not enlarged. The tissues were moist and on pressure a thin, bloody fluid exuded copiously. The gall-bludder contained a large quantity of tough yellowish green bile.

Liver, Microscopic Examination: The parenchyma of the liver showed extensive tough infiltrations, especially the mid$\mathrm{d}_{1}$ ) aciuons zonc. The liver cells in the center of the acini showed purcuelyymatous degenerntion, partly sclerotic, partly necrotic. lruegularly scattered were seen latger and smaller hemorrhages (extramedullary blood formation) as well as lurger and smaller round cells, with deply stnined nuelei. Some of these were round, others lobuluted. The periportal comnective tissue was very mueh lhickened and infiltrated with round cells; ulso the walls of the hepatic artery and portal vein. Van Giesen's stain showed regularly distributed interstitial induration.

Kidneys, Macroscopic Examination: The two kicheys together weighed $100 \mathrm{gm}$. (31/2 $0 \%)$; adrenals $6 \mathrm{gm}$. (90) gr.). 'The remal capsule was easily detached. The surface was Jobulated and of a pale yellow, with numerous punctiform hemorthages. On section the cortex was found to be enlarged, of a pale yollow color and slightly protuberant. The cortical marking was only present in form and was very much obliterated. Snall white stripes were visible. The pyramids were somewhat more sharply defined by a more ycllowish color. 'The left kidney presented practically tne same appearance ns the right one, but was somewhat redder in color. 'The mucouss membrare of the renal pelvis was pale, with numerous punctiform lemorrlanges.

Kidueys, Microscopic Exumination: Both kidneys showed severe jarenchymatous degeneration, with extensive necrosis of the epithelium. Slight hemorrlages into the glomeruli and uriniferous tubules were foumd. Hyaline masses were found in some of the canuls, especially in the collecting ducts. On frozen section and with the Sulan stain fatty morphosis was found in some of the tortuous and struight uriniferous tubules.

Heart: The leart weighed $50 \mathrm{gm}$. (11/3 $0 \%$.) and was well contracted. The musculnture was of a cloudy, gray, yellow. ish color. Numerous small liemorrhages werc found benenth the epicardium. The valvular apparatus was intact, the form- men ovale closel. The intima of the large vessels, as well as that of the valves, was slightly discolored, a yellowish green. Lungs: The lungs weighed $175 \mathrm{gm}$. (5 oz. j25 gr.). Right lung: In the upper lobe there was an irregular slightly de. pressed circumseribed spot about the size of a twenty-fivecent piece. The spot was discolored and dark gray in appearanee. In the lower lobe there wa also a spot alout the size of a ten-cent piees, which was also depressed and dark gray in appearance. On section the entire pulmonary parenchyma seemed to be studled with the above-described areas. It was entirely airless, and on pressure a dark red turbid fluid exuded. Left lung: In the upper and lower lobes similar arens were found.

Stomach: The stomach contained a small quantity of fluid, The mucous membrane was atrophic and showed numerous punctiform hemorlhages.

Bowels: A small quantity of greenislı white masses were found in the duodenum. The mucots membrane of the jeju. num was also atroplic. In the eolon a large quantity of fluid and dark green feces were fouml. The mucous membrane of the transverse colon was very much injected; that of the ascending and descending colon was pale.

'The autopsy findings in this case correspond closely to those in the case described by Banti. IIere we also fiud the fibrous changes in the trubecula and the follicles of the splcen, and a great diminution of the colls. We also have a diminution of lewkocytes and the red corpuscles.

'The diagnosis of this case as belonging to the class of cases described under the term of pseudoleukemic anemia of infancy can scarcely be questioned. 'The low leukocyte count, the diminution of the red blood-corpuscles below half the normal, together with the enlargement of the spleen, moderate enlargement of the lymphnodes distinguishes it from leukemia and simple or pernicious forms of anemin. Whether this case is to be eonsidered a secondary anemia in comnection with the raclitis with a toxic basis; or, as a distinct organic disease, it is difficult to decide. The organic changes in the spleen and liver would indicate a primary diseased condition of that most important blood-making organ, the splecn. 'The evidence seems about equally divided and in view of the fact that so far but tew autopsics have been recorded in these cases, it is impossible to come to any definite conclusion in this single case. I hope that by having carefully studied and recorded the findings of this interesting case I have added a small mite to the literature of this important disease.

$$
6101 \text { Penn Avenue. }
$$

\section{ABSTRACT OF DISCUSSION}

Dr. J. F. Hultakn, Chicaro: In the last few years I he hand a number of similar cases which have made me think a good deal of this question. The ense just reported undoubt. edly belongs to that class of anemias of infancy which we call, for want of a better name, pseudo-leukemia. Some of my recent cases lave shown a combination of leukemic and leuka. nemic changes; that is, not only very marked qualitative and qunntitative changes of the lencocytes, but also marked alterations in the number and form of the red blood-corpuseles. Others run into a true leukemia und end in denth. Dr. Elterich's ease does not belong to this last special class and I am glad he mentioned that. Assuming that all the lenkocytes develop from the small lymphoid cell, those infections characterized by specific changes in the blood must be due to an irritation of the leucogenic system. Whether or not this condition is recognized at an carly stage, or advances to a splenic ancmia or Janti's disease before it is dingnosel nakes no difference. It is the same disease, only a later stage. I think we are almost smothered by a multitude of mames in the deseription of the so-ealled pseudo-leukemia of childhood. Any severe dis- 
turbance of the infantile leucopoietic system may in the first place produce partial or complete lenkemia. Whether we have a polynuclear or a mononuelear or a lymphatic leukemia, does not alter the case. It simply depends on the hastening or the slow. ing of the processes of maturation of the lymphocytes. Later on, after months or years the patients come to our oflices, and finding a large spleen, ascites, etc., we call it Banti's disease. The pathogenesis of infuntile psendo-leukemia does not resicle in the spleen alone. It depends on infectious, or toxi-infectious lesions of the lymphoid tissues. I think it. is easy to believe that as long as there is some leucopoietic tissue left there may be an acute leucogenic crisis. The blood exumination then would show a lenkenia. A blood examination made later on will likely show a splenic anemia, or an ancmie primilive of French writers, a leukunemia, or I3anti's disease, etc. Or the patient may go on to a pernicious anemia. This is also easy to understand if we consider that in jrritation of the leucopoietic cells we must also have a hematopoietic irritation. I think that all these anemias should be looked on as the results of an infection of the lymphoid or leukopoietic system in the gastro-intestinal canal, which may or may not be noticed at the time of its occurrence. Its various forms are nothing but the variations common to all individuals. In childhood the death of these patients is due to exhaustion. Perhaps there are toxic symptoms, but they usually die with the clinical picture of asthenia, though this is often preceded by bronchopneumonia. I think the abdominal symptoms are always at the bottom of this condition, though they are not usually recognized.

Dr. C. F. Warrer, Fort Madison, Iowa: I have seer three cases that would come under the author's name of the infection. The first patient, after five months, died. The second after three months died, and the third recovered. The recovery may throw a little doubt on my dingnosis, but I did the best I. could with the means at hand. We had a symptom-complex of an affection that we may class under the diagnosis namex by the essayist. The children all had the symptoms that luve been named briefly by the anthor. There was anemia, there were purpuric spots and a history of syphilis in the ancestry of the first two; in the last one, a gastro-enterie trouble with numerous and profuse hemorrhages from the intestinal canal. The treatment in the first two eases was addressed chiefly to the origin of the disease, $i . e$., the sypliilitic condition, and in the last case it consisted mainly in the administration of Fowler's solution, iron and remedies addressed to the gastrointestinal tract. This child, after ten years, is still in perfect health.

Dr. Theonome J. Euterich, Pittsburg, Pa.: I am not in a position to classify these cases according to their pathologic findings. I latd only one anse in which the dingnosis seemed positive. In one or two other cases no blood count was made and the patients died before they could be removed to the hospital for observation. 'The symptoms were those of rickets, with an enlargement of the spleen and anemia.

\section{CHOKED DISC IN ITS RETATTION TO CERE- BRAL 'JUMOR AND TREPHINING *}

\author{
ALFRED SAENGER, M.D. \\ Neurologlst to the IIospltal St. Georg \\ HAMBURO, GLRMANY
}

When $I$ was invited to be the gruest of the Section on Nervous and Mental Discases of the $\Lambda$ merican Medical Association, and to read a paper before this famoms body, I felt highly honored, and it was with the greatest pleasure and thanks that I accepted this invitation. Having leave to choose the subject I did not hesitate long and selected the important theme of choked disc in its relation to cerebral tumor and trephining.

There is hardly any point which has for so long a time been subject to as much controversy as the patho-

* IRend in the sectlon on Nelvous and Mental Dlaenfeg of the Ainerican Medical Association, at the Slxty-flist Annual Session, beld at St. Louls, June, 1010 . genesis of choked disc. In spite of numerous works, experiments, clinical observations and pathologic-anatomic investigations, we have not suceceded in bringing about an agreement between the various investigator's on this topic. Just lately the old quarrel on the pathogenesis of choked dise has become active again in Germany.

Surgical experience being, to my mind, of great importance for clearing up the origin of choked disc. I was convinced that America would be the best formm for discussing this question, because America possesses a greater experience on the effect of and indications for trephining in cercbral tumor than we do in Germany, thanks to the studies and works of Taylor, Mills, Spiller and Frazier, De Schweinitz, Weisenburg, Putnam, Kunpp, James Bordley and also to the new methorls of Harvey ćushing, not forgetting, however, Iingland's contributions, by Horsley, Gowers, Gunn and Leslie Jaton.

The fact that I was an ophthalmologist at first and devoted myself to neurology later has brought it about that I have been occupjed for twenty years with studying the changes of the fundus of the eye in diseases of the brain.

By request of Professor Uhthoff of Breslan, I made a report on the pathogenesis of choked disc before the seventy-sixth Versammlung Dentscher Naturforscher und Aerzte in Breslau in 1904. Since that date so much new work has been published, that I deem it necessary to give you a brief outline of the stand we take on this important question in Germany.

\section{RLVIEW. OF WORK AND THIEORIES ON CHOKED DISC}

'Tuerck was the first, who in 1853 , when describing a case of cerebral tumor with retinal hemorrhage expressed the idea, that the changes in the fundus of the eye were due to increase of intracranial pressure. However, only in 1860 the scientific world became acquainted with the so-called choked disc through Albrecht von Graefe's work on complications of optic nerve-inflammation with brain diseases. Von Graefe saw the cause of choliced disc in brain pressure, due to cerebral tumor, the sinus cavernosus being thus compressed and the voiding of both the vena oplathalmica and the vena centralis retine being inhibited; bringing about dilatation and twisting of the retinal veins as well as edematous swelling of the optic disc. He explained the inflammatory changes, first, as originating from retinal extravasations of blood; secondly, from the irritating effect of swelling of the optic disc, still increased by toughness of the scleral ring.

Von Graefe's hypothesis, however, soon encountered opposition. Hughlings-Jackson took the optical affection for a reflex symptom, but it was the anatomic facts found by Sesemann which principally disproved the theory, It was he who proved that the central retinal vein has an off-flow into the facial veins, quite indejendent of intracranial pressure. Moreover, Sesemann argued that compression of the sinus cavernosus could not be effected as easily as one might think. Later these statements made by Sesemann in 1869, though accepted everywhere, even by von Graefe himself, have met opposition from the well-known anatomist, Merkel, and from Gurwith, who, on the basis of extensive anatomic investigations, argued that the greatest part of the orbital venous blood flows into the sinus (avcrnosus. Quite recently J. Tudeich and Krïdener have endeavored to uphold the old theory of von Graefe 